\title{
De relatos de anticonquista, coleccionismo y musealizaciones: François Machon en la Patagonia (1892)*
}

\section{Resumen}

En 1892, el médico suizo François Machon realizó una expedición a la Patagonia, Argentina, cuya finalidad era buscar tierras susceptibles de ser colonizadas a gran escala. Durante su viaje dio forma a un relato en el que dejó consignada su experiencia; al tiempo, realizó fotografías e hizo acopio de numerosos objetos y restos humanos que, años después, donó a diferentes museos. Este trabajo tiene como finalidad examinar críticamente este viaje y sus consecuencias: a partir del análisis del relato producido por Machon y asociando este con las colecciones museísticas queremos poner en evidencia los estrechos vínculos entre los proyectos de colonización decimonónicos, el desarrollo de las disciplinas científicas y la constitución de colecciones. Al tiempo, queremos mostrar cómo la mirada y el discurso de Machon sobre la Patagonia se perpetuaron y se propagaron -en el tiempo y en el espacio- a través de las vitrinas de un museo.

\section{Palabras clave}

Tesauro: Argentina, colonización, relato, colección, museo.

Referencia bibliográfica para citar este artículo: Sánchez del Olmo, Sara. "De relatos de anticonquista, coleccionismo y musealizaciones: François Machon en la Patagonia (1892)". Anuario de Historia Regional y de las Fronteras 26.2 (2021): pp. 21-47.

Fecha de recepción: 29/07/2020

Fecha de aceptación: 9/09/2020

Sara Sánchez del Olmo: Doctora en Historia de América por la Universidad de Valladolid, España. Master en Estudios Amerindios por la Universidad Complutense de Madrid, España. Licenciada en Filosofía y Letras por la Universidad de Valladolid, España. Conservadora (curadora) responsable de las colecciones americanas del Museo de Etnografía de Neuchâtel, Suiza. Investigadora asociada en el Instituto de Historia y Antropología de las Regiones de la Universidad de Lausana, Suiza. Correo electrónico: Sara.SanchezDelOlmo@ne.ch. Código ORCID: 0000-0002-5370-9326.

\footnotetext{
${ }^{*}$ El trabajo forma parte de un proyecto de investigación sobre los viajes y exploraciones realizados por el médico suizo François Machon en América del Sur entre 1891 y 1933. Durante sus periplos, Machon constituyó importantes colecciones de objetos que, en su mayor parte, fueron donadas al Museo de Etnografía de Neuchâtel (Suiza). El objetivo prioritario de nuestro proyecto es la reconexión entre la materialidad y la retórica, es decir, entre los objetos y los textos. Al tiempo, nuestra investigación busca analizar los diferentes modos de exposición, de interpretación e, incluso, de ocultación ligados a esos objetos una vez que se produjo su entrada en el museo. Se trata de un proyecto independiente y unipersonal sin financiación pública o institucional.
} 


\title{
Of Anticonquest Stories, Collecting and Musealizations: François Machon in Patagonia (1892)
}

\begin{abstract}
In 1892, the Swiss physician François Machon carried out an expedition to Argentinean Patagonia. It's purpose was to look for lands to be colonized on a large scale. During his trip, to record his experience, he wrote a travel diary; at the same time, he took photographs, collected numerous objects and human remains that, years later, he donated to different museums. The objective of this article is to critically examine this journey and its consequences: from the analysis of the diary and correlating the text with the museum collections, it is intended to evidence the close links between the colonization projects in Nineteenth-century, the development of scientific disciplines and the creation of collections. Additionally, it is intended to illustrate how Machon's perspective and discourse about the Patagonian were perpetuated and spread - in time and in space - throughout the showcases of a museum.
\end{abstract}

\section{Keywords}

Thesaurus: Argentina, Colonization, Diary, Collection, Museum.

\section{De histórias de anticonquista, recolha e musealização: François Machon na Patagónia (1892)}

\section{Resumo}

Em 1892, o médico suiço François Machon fez uma expedição à Patagônia Argentina, cujo objetivo era procurar terras que pudessem ser colonizadas em larga escala. Durante sua viagem, a fim de deixar registrada a sua experiêcia, ele escreveu um relato; ao mesmo tempo, fotografou e colecionou inúmeros objetos e restos humanos que, anos depois, doou a diferentes museus. O objetivo deste trabalho é examinar criticamente essa viagem e suas conseqüências: a partir da análise do texto produzido por Machon e associando o texto com às coleções museais, queremos mostrar os vínculos estreitos entre os projetos de colonização do século XIX, o desenvolvimento de disciplinas científicas e o constituição de coleções. Ao mesmo tempo, queremos mostrar como o olhar e o discurso de Machon sobre a Patagonia foram perpetuados e propagados - no tempo e no espaço - através das vitrines de um museu.

\section{Palavras-chave}

Tesauro: Argentina, colonização, relato, coleção, museu. 


\section{Introducción}

Numerosos trabajos vinculados a la historia de la ciencia aparecidos en los últimos años han prestado atención al papel de los aficionados o científicos vocacionales en el proceso de construcción del conocimiento. Más allá de la pertinencia o no de utilizar estas categorías, todas ellas producidas por el mundo académico. ${ }^{1}$ Lo cierto es que esta nueva aproximación ha permitido que diferentes actores, hasta ahora no considerados como protagonistas, hayan sido incorporados -como elemento fundamental- a las investigaciones. Esto es especialmente evidente en el caso de las instituciones museísticas, donde el papel jugado por los (denominados) científicos vocacionales ha sido determinante en el proceso de constitución de sus colecciones. ${ }^{2}$

El trabajo que presentamos aquí -al igual que las reflexiones y cuestiones que planteamos- se insertan en un proyecto de investigación sobre los viajes y exploraciones realizados por el médico suizo François Machon en América del Sur entre 1891 y $1933 .{ }^{3}$ A lo largo de sus periplos, Machon constituyó importantes colecciones de objetos que, en su mayor parte, fueron donadas al Museo de Etnografía de Neuchâtel (Suiza).

El objetivo prioritario de nuestro proyecto de investigación es la reconexión entre la materialidad y la retórica, es decir, entre los objetos y los textos: revisitando y analizando de manera crítica la producción escrita de Machon y asociando con las colecciones custodiadas en las instituciones museísticas, buscamos reconstituir la dinámica de sus viajes, así como examinar sus prácticas y estrategias de recolección de objetos. Finalmente, nuestra investigación busca analizar los diferentes modos de exposición, de interpretación e incluso de ocultación ligados a esos objetos una vez que se produjo su entrada en el museo.

Entre los viajes realizados por Machon en América del Sur sobresale, sin duda, su expedición a la Patagonia Argentina en 1892. ${ }^{4}$ Por razones muy diversas,

\footnotetext{
${ }^{1}$ Axel Lazzari y Regula Nigg, "El médico alemán, o cómo reconocer una etnografía-accidente en la antropología Argentina", El americanismo germano en la antropología Argentina, compilado por Lena Dávila y Patricia Arenas, (Buenos Aires: Ediciones CICCUS). En prensa.

${ }^{2}$ Para indagar sobre el papel de los (llamados) científicos vocacionales y aficionados en los procesos de conformación de las colecciones de los museos, véase Susan Leigh Star y James Griesemer, "Institutional Ecology, Translations, and Boundary Objects: Amateurs and Professionals in Berkeley's Museum of Vertebrate Zoology", Social Studies of Science, vol. 19 (1989): 387-420; Morgan Meyer, "On the Boundaries and Partial Connections between Amateurs and Professionals", Museum and Society, vol. 6.1 (2008): 38-53.

${ }^{3}$ Esos viajes no se produjeron de manera continuada: hubo una primera fase muy activa, entre 1891 y 1901 , que se corresponde con el periodo en el que Machon residió de manera estable en Argentina, y una segunda marcada por los viajes esporádicos (1925-1926 y 1931-1933) que se corresponde con el periodo en el que Machon se instaló de nuevo en Europa.

${ }^{4}$ Los conflictos entre Chile y Argentina por los límites y la posesión de la Patagonia se sucedieron durante todo el siglo XIX. En 1881, el denominado “Tratado de Límites” fijó la demarcación precisa. Pese a todo, los problemas en torno a las fronteras de este territorio no han finalizado. En el caso argentino, la primera definición legal de la Patagonia se produjo en el marco de los preparativos de la denominada "Conquista del Desierto"; en 1878 se creó la Gobernación de la Patagonia, y en 1882 se dividió en dos sectores
} 
ni el periplo ni las colecciones recogidas durante el mismo han recibido hasta ahora la atención de los especialistas. De hecho, el texto publicado por el suizo es (casi) desconocido. Este olvido es sorprendente por dos razones: por un lado, su viaje constituye una experiencia altamente singular ya que está directamente ligada a un proyecto de colonización y blanqueamiento del territorio argentino a gran escala; por otra, el relato nacido de ese periplo constituye una fuente privilegiada de información en relación al espacio patagónico de finales del siglo XIX y, sobre todo, en relación a sus habitantes. En lo que respecta a los objetos acopiados, estos no han sido estudiados en profundidad y su inclusión de pleno derecho en las colecciones museísticas es (relativamente) reciente. ${ }^{5}$

Desde el punto de vista estructural, el presente trabajo se articula en cuatro epígrafes: en primer lugar, abordamos la figura de François Machon y analizamos el proyecto colonizador del que formó parte activa enmarcándolo en el contexto socio-político y económico de la Argentina de fines del siglo XIX; en segundo lugar, ahondamos en los imaginarios históricos construidos en torno a la Patagonia Argentina, el espacio a colonizar, para pasar después a analizar las pervivencias y las rupturas de ese imaginario en el relato producido por Machon; en tercer lugar, abordamos el análisis de los objetos recogidos por el suizo en el terreno prestando especial atención a su naturaleza, así como a las prácticas de adquisición; en cuarto lugar, profundizamos en el destino de dichos objetos y mostramos el proceso de musealización que experimentaron tras su llegada a Europa. Finalmente, presentamos nuestras conclusiones y señalamos algunos de los caminos por los que creemos que deberían transitar nuestras futuras investigaciones en relación a la temática aquí presentada.

Con el análisis del periplo de Machon en Patagonia queremos mostrar, en primer lugar, los estrechos vínculos entre los procesos de colonización, el desarrollo de las disciplinas científicas y la constitución de colecciones museísticas; en segundo lugar, queremos poner de manifiesto como relato ${ }^{6}$ y colección constituyen un binomio

denominados "territorios de la Pampa" y "territorios de la Patagonia". En 1884 se crearon los Territorios Nacionales de Río Negro, Neuquén, Chubut, Santa Cruz y Tierra del Fuego. Esta división puso fin a la unidad administrativa de la Patagonia Argentina. No obstante, todos esos territorios siguieron formando parte de la Patagonia, entendida esta como región histórica y cultural.

${ }^{5}$ En el caso de los objetos donados al Museo de Etnografía de Neuchâtel la mayor parte de ellos no fueron catalogados hasta el año 2013.

${ }^{6}$ El viaje de Machon fue publicado en 1893 en la Bibliothèque Universelle et Revue Suisse. Tomes LIX et LX bajo el título "En Patagonie. Notes d'un explorateur". Este es el texto que utilizamos como fuente en nuestro trabajo. Todas las traducciones son nuestras.

La Bibliothèque universelle fue una revista mensual nacida en Ginebra en 1816 e inspirada en la "Biblioteca británica". Poseía un doble carácter literario y científico. Después de unos años convulsos, en 1861 se fusionó con la Revue suisse. A partir de 1866, bajo la dirección de Edouard Tallichet, la revista se convirtió en un referente en la Suiza francófona en gran medida gracias a la notable reputación de sus colaboradores. Según algunas fuentes, Tallichet controló de manera férrea el contenido publicado evitando todos aquellos textos sospechosos de ser inmorales o de desviarse de la doctrina protestante. Según esas mismas fuentes, la reacción frente a este control hizo que se fundaran en los años 1880-90 otras revistas como La Suisse romande (1885) o la Revue de Genève (1885-1886). Véase Selina Follonier, «Devenir soi-même». Paris, catalyseur de l'identité romande: Reconversions d'écrivains transfuges, 1880-1900 (Mémoire de maîtrise, 
que debe ser analizado de manera conjunta; finalmente, nuestra voluntad es mostrar cómo la mirada y el discurso de Machon sobre el espacio patagónico se perpetuaron y se propagaron -en el tiempo y en el espacio- a través de las vitrinas de un museo.

\section{François Machon, un suizo en la tierra maldita}

François Machon nació en 1862 en Neuchâtel (Suiza) en el seno de una familia de origen francés. Tras realizar sus estudios en Friburgo de Brisgovia, Ginebra y Berna, obtuvo su diploma de médico en esta última universidad. ${ }^{7}$ Después de una tentativa infructuosa por convertirse en oftalmólogo, se embarcó hacia el Nuevo Mundo donde arribó en 1887. Las razones de la marcha de Machon a América permanecen oscuras; es muy posible que su partida esté directamente vinculada a la quiebra financiera de su padre en 1886 que provocó la expropiación de la casa familiar así como la venta -en subasta pública- de todo su contenido. ${ }^{8}$

Instalado en Argentina, trabajó primero como médico de familia en Buenos Aires para después establecerse en Rosario donde ejerció su profesión durante catorce años. Durante su estancia en América, Machon realizó diferentes viajes por el extremo sur del continente. No obstante, ninguno de ellos se asemeja a su periplo en la Patagonia: el suizo fue contratado en el marco de una empresa de exploración del territorio argentino destinada a una finalidad precisa: "buscar, en las vastas soledades situadas entre el Río Negro y el Río Chubut, tierras susceptibles de ser colonizadas a gran escala". ${ }^{9}$ El proyecto, de una dimensión colosal, respondía a la iniciativa personal del Barón Maurice de Hirsch, considerado como el gran promotor de la emigración judía en América del Sur. ${ }^{10}$ En 1891, De Hirsch fundó la Jewish Colonization Association (ICA o JCA) cuyo objetivo era comprar tierras en Argentina, Brasil, Canadá, y Estados Unidos para instalar en ellas a judíos europeos como colonos

Université de Lausanne, 2017) 13.

En 2013 se publicó en Argentina una versión del texto de Machon traducida al español. La edición fue realizada por Jorge F. Machon, nieto de François Machon, y Francisco N. Juárez. Aunque incorpora algunas notas de página, no se trata de un estudio crítico. Jorge F. Machon y Francisco N. Juárez, eds.), Patagonia 1892. Diario del explorador Suizo Dr. Francisco Machón (Buenos Aires: Editorial Dunken, 2013).

7 Théodore Delachaux. «Notes biographiques. Dr. François Machon, médecin et explorateur». Documento mecanografiado inédito. Archivos del Museo de Etnografía de Neuchâtel, Neuchâtel (Suiza), Fondo Machon.

${ }^{8}$ L'Impartial, 16 mars 1886 y Feuille d'avis de Neuchâtel, 19 juin 1886, 29 mars 1887 y 5 avril 1887.

${ }^{9}$ François Machon, «En Patagonie. Notes d'un explorateur», Bibliothèque Universelle et Revue Suisse, Tome LIX, première partie (1893): 79.

Según las informaciones contenidas en las notas biográficas redactadas por T. Delachaux, la oportunidad de llevar a cabo esta misión se la ofreció uno de sus clientes en Rosario, quien era representante de la Jewish Colonization Association. Machon menciona en su relato la existencia de un informe especial en el que explicitaba las consideraciones técnicas y económicas, pero, por el momento, no hemos logrado acceder a ese documento; tampoco poseemos información precisa sobre los términos del acuerdo suscrito por Machon para llevar a cabo esta misión (contrato, salario, etc) ni sobre el itinerario que debía seguir y si este se vio alterado.

${ }^{10}$ Dominique Frischer, "Le baron Maurice de Hirsch et les Juifs de Russie. Entre philanthropie et utopie", Archives Juives, vol. 44 (2011): 70-82. http://doi.org/10.3917/aj.441.0070 (30/06/2011). Consultado el 17 de noviembre de 2018 
agrícolas. Fue fundamentalmente en Argentina donde el proyecto del Barón tomó forma. De esta manera, con la finalidad de localizar los espacios más convenientes para instalar a esos judíos, Machon inició un viaje de casi 2.600 kilómetros y, durante cinco meses, ${ }^{11}$ recorrió este inmenso territorio acompañado del geólogo de origen suizo Santiago Roth. (Figura 1).

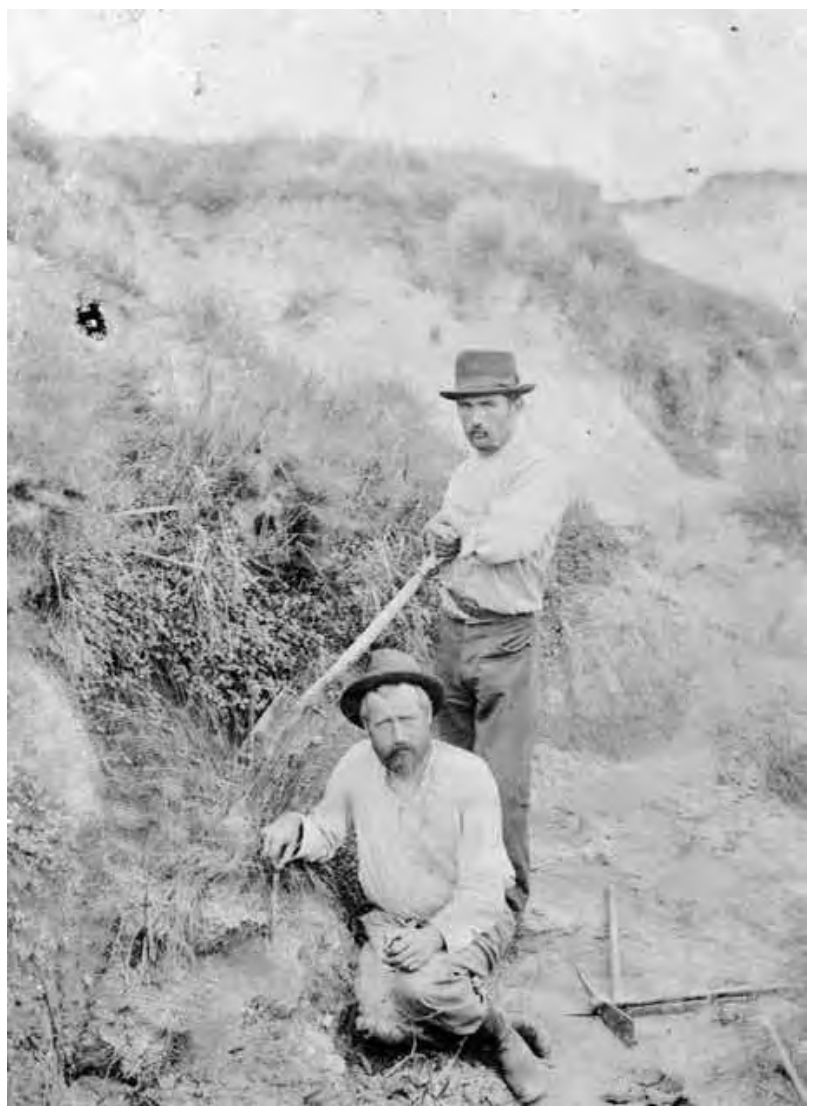

Figura 1. Autor desconocido. "Santiago Roth (de pie) junto a François Machon durante su exploración en Patagonia" Patagonia (Argentina), 1892. Museo Hrisuk, Encarnación (Paraguay) ${ }^{12}$

El viaje de Machon se inscribe dentro de un proyecto filantrópico que es, ante todo, un proyecto de colonización física y cultural. El plan superaba con creces las preocupaciones humanitarias de un rico hombre de negocios judío ya que las motivaciones de De Hirsch no pueden desligarse de los intereses del Estado argentino.

\footnotetext{
${ }^{11}$ Machon partió de Buenos Aires el 4 de marzo de 1892, abandonó la Patagonia el 9 de julio y llegó en barco a Buenos Aires el 21 de julio de ese mismo año.

${ }^{12}$ La imagen ha sido publicada en la obra Louis de Boccard: Un fotógrafo en la Triple Frontera, 1889-1956, editada en 2017 por André Heráclio do Rêgo y Rubén Capdevila. Desconocemos cómo llegó a formar parte de las colecciones del Museo Hrisuk y por el momento no hemos logrado saber si esta institución posee más fotografías vinculadas a Machon.
} 
A lo largo del siglo XIX la Argentina estuvo sumida en un proceso de construcción nacional; tras el fin de las luchas intestinas que habían dividido la nación desde la Independencia, esta buscaba dotarse de una identidad colectiva. Para conseguirlo era necesario lograr, previamente, la completa y real unificación del país, así como la delimitación precisa de sus espacios físicos de referencia. Sin embargo, ambos deseos se veían frenados por un enorme obstáculo: los vastos territorios aún no sometidos al poder del Estado. Esos lugares, al igual que sus habitantes, eran -para las élites argentinas de la época- sinónimo de barbarie.

Políticos e intelectuales desarrollaron entonces un discurso ideológico marcado por una alteridad radical que ponía el acento en la oposición entre la civilización (representada por el Estado) y la barbarie (representada por los habitantes de estos espacios no domesticados). Una dicotomía que estaba cargada de connotaciones morales y que tuvo severas consecuencias socio-económicas y políticas. La construcción de la nación, vista como la extensión de la civilización, implicaba asimilar (e incluso suprimir) todos los elementos susceptibles de impedir o frenar este sueño.

Al mismo tiempo, este proyecto de construcción nacional suponía colonizar estos territorios con poblaciones consideradas más apropiadas que los autóctonos. A ojos de las élites argentinas, los europeos blancos eran el reemplazo perfecto para lograr sus objetivos. Como bien lo señalaba en 1852 Juan Bautista Alberdi, uno de los miembros más eminentes de este grupo de intelectuales, con sus inmigrantes, Europa podría aportar a la Argentina "su espíritu nuevo, sus hábitos de industria, sus prácticas de civilización". ${ }^{13}$ De manera paralela, el Estado argentino inició una serie de campañas militares destinadas a incorporar esos inmensos territorios no controlados y susceptibles de ser explotados en beneficio de la economía del país. La conquista se inició durante el mandato de Nicolás Avellaneda (1874-1880): presionado por los estancieros y grandes propietarios (que querían disponer de más tierras), en un contexto de crisis económica, y con una demanda creciente de bienes alimentarios por parte de los mercados internacionales, el presidente decidió poner fin a las relaciones (tradicionalmente) pacíficas establecidas con los pueblos autóctonos y con la ayuda de Alfonso Alsina, su ministro de Guerra y de Marina, Avellaneda lanzó una primera campaña militar sobre La Pampa.

A la muerte de Alsina, el cargo fue ocupado por Julio Argentino Roca: considerado por la historiografía oficial Argentina como uno de los constructores de la nación, Roca fue el iniciador de una operación militar conocida como "Campaña del Desierto" (1879) que permitió hacer avanzar las fronteras del Estado hasta las riberas del Neuquén y del Río Negro, en los márgenes de la Patagonia. ${ }^{14}$ Esta campaña tuvo

\footnotetext{
${ }^{13}$ Juan Bautista Alberdi, Bases y puntos de partida para la organización politica de la República Argentina. (Buenos Aires: Biblioteca del Congreso de la Nación, 2017). Los fundamentos de la política migratoria Argentina están contenidos en la Constitución de 1853. El texto adoptó la doctrina de Alberdi, es decir, "gobernar es poblar". El preámbulo constitucional alienta la inmigración considerada como uno de los elementos indispensables para construir la nación.

${ }^{14}$ Es necesario señalar que la acción militar no contó con un apoyo unánime. Existieron también posturas
} 
tal eco que, finalmente, toda la empresa de conquista de La Pampa y de la Patagonia (desarrollada entre 1875 y 1885) recibió el nombre de "Conquista del Desierto". Tras su regreso triunfal a Buenos Aires, Roca fue elegido presidente (1880-1886), puesto desde el que continuó el avance sobre la Patagonia.

La Conquista del Desierto emprendida por las autoridades argentinas, que buscaba remplazar la "barbarie" por la civilización, se desarrolló bajo un doble sistema que combinaba las fuerzas del Estado con fuerzas privadas; de esta manera, el avance militar corrió paralelo a la creación de asentamientos agrícolas (en ocasiones grandes haciendas), y a la penetración del capital comercial. Finalmente, para lograr un verdadero control del territorio se necesitaba un conocimiento preciso del mismo; en esa óptica se enmarcan las múltiples misiones científicas destinadas a producir un saber sobre ese espacio y, particularmente, sobre las poblaciones (sometidas) que lo ocupaban. ${ }^{15}$

La inserción de estos territorios a las fronteras de la nación implicó la elaboración de un discurso ideológico destinado a justificar su conquista: recuperando retóricas y mitos precedentes, el poder hegemónico desarrolló un relato espacial que presentaba estos territorios como vacíos. Para las élites intelectuales y políticas, el término "desierto" constituía una metáfora de la ausencia de civilización y, al mismo tiempo, una denominación que servía para justificar su poblamiento y, sobre todo, su blanqueamiento.

Sin embargo, estos territorios no estaban vacíos sino habitados por diferentes grupos étnicos. Pero el indio encarnaba lo indeseable de esa comunidad imaginada que el Estado se esforzaba por construir ${ }^{16}$ por lo que era imprescindible someterlo. Para lograrlo, se diseñó un programa cuyos objetivos principales fueron no tanto la confrontación directa y la eliminación física sino la captura de

(minoritarias) que apostaban por la negociación con los autóctonos. Sin embargo, desde que Roca asumió el Ministerio de Guerra estas posiciones fueron descartadas.

${ }^{15}$ En ese marco se produjo, por ejemplo, el primer viaje de Francisco Pascasio Moreno en 1873: Moreno recorrió el interior de la Patagonia siguiendo el curso del Río Negro, desde Carmen de Patagones. En los años sucesivos, Moreno exploró áreas del río Chubut, del río Santa Cruz y del Nahuel Huapi. Estas actividades científicas dieron lugar al nacimiento y desarrollo de numerosas instituciones museísticas. No obstante, en el caso argentino, como bien han señalado diferentes autores, los espacios institucionalizados destinados a albergar esos "tesoros" recogidos sobre el terreno están vinculados más a iniciativas individuales que a una acción directa del Estado. Sobre este tema véase Irina Podgorny y otros, "Caballeros de la noche. Antropología y museos en la Argentina de las últimas décadas del siglo XIX", Las ciencias en la formación de las naciones americanas, coord. Sandra Katja Carrillo Zeiter (Madrid: Iberoamericana, 2014) 201-228. Compartimos en gran medida ese planteamiento, pero es importante señalar también que si bien el Estado no se encuentra tras la creación de esas instituciones, muchas de las misiones científicas (o de aficionados) que dieron lugar a la constitución de colecciones museísticas se realizaron con el apoyo estatal y, sobre todo, bajo el amparo del Estado.

${ }^{16}$ Como ha señalado Lenton, la fuerte asociación entre nación republicana y civilización implicaba que la pertenencia a un grupo indígena fuera vista como opuesta a la pertenencia a la nación en tanto individuociudadano y, en consecuencia, como un rechazo a la civilización misma. Diana Lenton, "De centauros a protegidos. La construcción del sujeto de la política indigenista Argentina desde los debates parlamentarios. 1880-1970, (Tesis doctoral, Universidad de Buenos Aires, 2005) 171. 
las poblaciones indígenas no combatientes y muy especialmente la destrucción de sus modos de vida. Dicho plan implicaba el traslado forzoso, la dispersión de los grupos, la separación familiar, la desestructuración y, claro está, el disciplinamiento social. ${ }^{17}$ De esta manera, durante este proceso, una buena parte de los autóctonos que sobrevivieron a los enfrentamientos militares fueron deportados masivamente como cautivos- hacia la capital y, una vez allí, repartidos por diferentes ciudades del país. En numerosas ocasiones, los hombres fueron empleados como mano de obra forzosa en la construcción de ferrocarriles o como obreros agrícolas en las estancias. Otros fueron compelidos a enrolarse en el ejército. Finalmente, algunos fueron apresados o sufrieron el exilio. En lo que respecta a las mujeres y a los niños, en numerosas ocasiones, fueron repartidos entre familias acomodadas de Buenos Aires como servicio doméstico. ${ }^{18}$ Aquellos indígenas que permanecieron en sus territorios, fuertemente diezmados, vivieron la progresiva desarticulación de sus estructuras socio-económicas. El avance militar, que buscaba ante todo transformar de manera radical estos espacios, forzó a los indígenas a insertarse -como subalternos- en el Estado. A partir de ese momento, se fueron diluyendo - de manera progresiva- en la sociedad Argentina, siempre desde una posición de subordinación.

En este contexto se enmarca el viaje realizado por François Machon: en 1892 el suizo se lanzó a recorrer un país (aún) en construcción que acababa de insertar los territorios patagónicos al mapa de la nación. Durante los meses que duró su periplo se convirtió en un testigo privilegiado del proceso de construcción nacional y, sobre todo, en un informador de las consecuencias que este tuvo para las poblaciones indígenas que habitaban la Patagonia. Su relato constituye un testimonio excepcional sobre este espacio y sus habitantes en un momento crucial de la historia Argentina.

\section{El relato de Machon: pervivencias y rupturas del imaginario patagónico}

Alegoría de la ausencia, la Patagonia fue considerada durante largo tiempo como un lugar fabuloso e inaccesible. ${ }^{19}$ Las primeras exploraciones del territorio, limitadas exclusivamente a sus costas inmensas y áridas provocaron la construcción de una mirada marcada por la esterilidad. Al tiempo, el escaso contacto de los europeos con las poblaciones autóctonas que habitaban este espacio ayudó a propagar y consolidar la idea de un territorio vacío. Fue sin duda Darwin quien contribuyó de manera definitiva a la configuración de este imaginario: a partir de la publicación

\footnotetext{
${ }^{17}$ Florencia Roulet y María Teresa Garrido, “El genocidio en la historia: ¿Un anacronismo?”, Corpus, vol. 1, 2 (2011). http://journals.openedition.org/corpusarchivos/1159 (30/12/2011). Consultado el 19 de abril de 2019

${ }^{18}$ Sobre estas cuestiones véase Enrique H. Mases, Estado y cuestión indigena. El destino final de los indios sometidos en el fin del territorio. 1878-1910, (Buenos Aires: Prometeo libros/Entrepasados, 2002).

Es importante señalar también que algunos de esos indígenas fueron convertidos en piezas de museo, tanto en vida como después de muertos. Sobre este asunto véase Karina Oldani, Miguel Añón Suárez y Fernando Miguel Pepe, "Las muertes invisibilizadas del Museo de La Plata", Corpus, vol. 1,1 (2011). http://journals. openedition.org/corpusarchivos/986 (30/06/2011). Consultado el 2 de noviembre de 2020.

${ }^{19}$ Sobre la formación del mito patagónico véase Ernesto Livon-Grosman, Geografías imaginarias. El relato de viaje y la construcción del espacio patagónico (Rosario: Beatriz Viterbo Editora, 2003).
} 
de su obra en 1839, la Patagonia comenzará a ser (re)presentada como un espacio vacío, lleno de tierras estériles, despobladas y, sobre todo, inhóspitas. Profundamente influido por la mirada europea de la época que otorgaba un valor extremadamente positivo a los paisajes humanizados y, sobre todo, productivos, Darwin nos presenta un territorio miserable e inútil, marcado por la negatividad. A lo largo de su relato, el naturalista genera la impresión de un espacio antagónico del mundo civilizado, un lugar donde la naturaleza se impone y reina, incluso de manera tiránica.

Esta construcción del paisaje, marcada por la penuria y la devastación, tuvo una influencia determinante en los viajeros europeos posteriores de manera que en la mayor parte de los textos post-darwinianos, este territorio aparecerá como un espacio marcado por la monotonía, lleno de tierras inútiles y miserables. Una deficiencia que encontró su concreción en la noción de desierto.

No obstante, los viajeros no fueron los únicos en cimentar una imagen de la Patagonia: durante la segunda mitad del siglo XIX, en un contexto marcado por la anexión de estos espacios a las fronteras de la nación, las élites políticas e intelectuales argentinas desarrollaron también un discurso sobre este territorio. ${ }^{20}$ Dicho discurso, destinado a justificar el avance, se articuló (también) sobre la idea de vacío. La desertificación fue el argumento necesario para justificar la conquista. Pero la inserción buscada por el Estado no era simplemente una cuestión de límites territoriales y de posesión simbólica: la dominación suponía antes que nada la integración completa de estos territorios al sistema productivo de la nación. De esta manera, a partir de 1880, las retóricas estatales precedentes, que habían estado caracterizadas por la negatividad y la carencia, fueron desplazadas por una nueva discursividad: el "desierto" patagónico comenzó a ser presentado como un lugar susceptible de contener riquezas inesperadas, como un territorio potencialmente productivo destinado a insertarse en las nuevas lógicas económicas de la nación. Y así, bajo el pretexto del nomadismo indígena y de su incapacidad para trabajar la tierra, el Estado se esforzó por estimular la ocupación de la Patagonia y la instalación de colonos (fundamentalmente europeos) capaces de contribuir a "civilizar" este espacio y, al tiempo, insertarlo en los circuitos económicos. La imagen de un "desierto fecundable" comenzó entonces a instalarse en el imaginario colectivo. De esta manera, las élites argentinas reinventaron la Patagonia.

Machon es un heredero de esta mirada, pero es también un constructor de percepciones. En su texto se fusionan las observaciones ajenas (y asumidas) con las reflexiones personales y los comentarios subjetivos. Al mismo tiempo, como en otros muchos relatos de esa época, el texto del suizo constituye descripción y escritura de la naturaleza y de la cultura. En su escrito coexisten varios registros (informaciones botánicas, zoológicas, geomorfológicas, paleontológicas, históricas, económicas, socio-políticas, etnográficas...) que se articulan, se ordenan (y se desordenan) siguiendo el hilo narrativo de la propia expedición. No faltan tampoco las anécdotas

\footnotetext{
${ }^{20}$ Pedro Navarro Floria, "El desierto y la cuestión del territorio en el discurso político argentino sobre la frontera Sur", Revista de Historia complutense de historia de América, 28 (2002): 139-168.
} 
y las digresiones. De su escrito, extenso y rico, nos interesan fundamentalmente dos elementos: su visión sobre el territorio y su mirada sobre las poblaciones indígenas que lo habitaban.

En lo que respecta al territorio, a lo largo de todo su relato Machon asume y utiliza la noción de desierto para referirse a él; sus descripciones, en numerosas ocasiones articuladas con una formulación negativa, están marcadas por la carencia y la ausencia. Alejada del mundo, en su texto la Patagonia aparece como una "tierra de desolación", ${ }^{21}$ despoblada, donde la sequía ha dejado secuelas muy evidentes, manifestadas -por ejemplo- a través de la presencia de cadáveres de animales, una temática recurrente a lo largo de todo su relato. ${ }^{22}$ La ausencia de agua es, sin duda, el elemento retórico más utilizado: la sequía recorre todo el relato. Hay que tener en cuenta que las referencias a esta particularidad del territorio están directamente vinculadas a la misión del suizo, encontrar tierras susceptibles de ser cultivadas. Sin embargo, en nuestra opinión, en el caso de Machon este déficit (de agua) adquiere otra dimensión ya que todo su texto está atravesado por la idea de la carencia, no solo desde el punto de vista material sino, sobre todo, simbólico. Y la noción de desierto, bien presente, está íntimamente ligada no solo a las condiciones climáticas del espacio sino también a la carencia de civilización. ${ }^{23}$ La discursividad desplegada en el relato trasmite la idea de un territorio marcado por la ausencia total de potencial, y está marcada por una geopoética que pone el acento en la repetición visual y la penuria.

No obstante, pese a lo que pudiera pensarse, el relato de Machon no es monocromo: a lo largo de su proceso de escritura el suizo va modificando su visión de la Patagonia en función de su propia experiencia de campo. Como bien ha señalado Westphal, frente al territorio, el observador puede adoptar -al menos- tres puntos de vista: el endógeno, es decir, la perspectiva familiar y autóctona; el exógeno, la perspectiva que representa la mirada extraña y ajena (y que constituye la base de las representaciones exotizantes), y -finalmente- la perspectiva alógena, que se construye a partir de una mirada híbrida en la que el observador pasa por un proceso de familiaridad vital con el lugar pero permanece siempre ajeno (y exterior) a la realidad que está observando. ${ }^{24}$

Machon se sitúa, precisamente, en esta tercera perspectiva: su escritura, forjada al compás de la experimentación del territorio, permite al lector acercarse a una diversidad espacial habitualmente negada o ignorada. La descripción de su entrada en el valle de Limay constituye un buen ejemplo: en este pasaje, el suizo muestra su fascinación por lo que ve y señala que "haría falta una pluma de artista

\footnotetext{
${ }^{21}$ François Machon Tome LIX, première partie 103.

22 François Machon Tome LIX, première partie 110.

${ }^{23}$ Esta mirada está continuamente presente y no desaparece hasta la llegada del suizo al valle de Chubut cuando señala "finalmente entramos en una región civilizada". François Machon Tome LX, cinquième partie 296.

${ }^{24}$ Bertrand Westphal, La Géocritique. Réel, fiction, espace (Paris, Minuit: 2007) 208 y ss.
} 
para describir la belleza del paisaje". ${ }^{25}$ En ese momento, el viajero se transforma en voyeur y su experiencia del viaje deviene, antes que nada, experiencia visual. De esta manera, a lo largo de su descripción, vemos aparecer hermosos riachuelos, cumbres, nieve, ríos rugientes, un torrente y, finalmente, un bosque de cipreses "que recuerda los bosques de abetos de nuestra querida patria". ${ }^{26}$ Esta identificación de la belleza del paisaje visitado con el mundo de pertenencia aparece también en su descripción del Lago Nahuel Huapi, al que, según el suizo, "los Andes rodean como los Alpes al Leman". ${ }^{27}$ Es en ese momento cuando Machon se convierte en intérprete de esa realidad: si analizamos detalladamente sus consideraciones descubrimos que para el suizo la belleza del lugar está íntimamente ligada a su proximidad con su universo de referencia; las comparaciones con su país de origen le permiten integrar las "rarezas" estéticas, esos elementos que no se corresponden con el imaginario (occidental) construido alrededor de este territorio. Pero, sobre todo, estas analogías muestran que para el suizo, la belleza estaba necesaria e imperativamente vinculada a la presencia de vegetación y de agua.

Por otra parte, a lo largo de su texto, Machon muestra su profundo interés por las ciencias naturales. Sus prolijas descripciones de la fauna, la flora y la geología de este espacio ponen en evidencia la vocación científica del suizo hasta el punto de que no duda en desarrollar diversas hipótesis (incluso teorías) sobre la antigüedad o la desaparición de determinadas especies animales, una cuestión que suscitaba arduos debates en el seno de la comunidad científica de la época.

Finalmente, en su descripción del espacio patagónico, Machon insiste en la ausencia de población del territorio: la Patagonia es presentada de manera recurrente como un espacio vacío. Esa (permanente) deshumanización del espacio pone en evidencia las contradicciones de su texto ya que este, paradójicamente, está plagado de referencias a los grupos indígenas (pasados y presentes) que habitaban la región.

En su texto, Machon puebla el vacío. Precisamente, el trabajo de descripción etnográfica constituye, sin duda, uno de los elementos más interesantes de su relato. Sus testimonios dejan entrever su interés por las culturas indígenas y, sobre todo, la (fuerte) impresión que le produjo el contacto directo con esa alteridad radical. Sus observaciones nos permiten aproximarnos a los profundos cambios sufridos por los habitantes de este territorio tras la guerra de los años 80. Así, a lo largo del texto, Machon detalla los agudos efectos de la conquista de este territorio; efectos que se observan no solo en el espacio sino también en los cuerpos de los indígenas. En su relato, el suizo deja entrever que las transformaciones provocadas por la ocupación habían sido muy negativas: habla de colonias "que no existen más que sobre el papel", ${ }^{28}$ del acaparamiento de tierras agrícolas por parte de grandes propietarios (la mayor parte, según él, antiguos oficiales del Ejército que habían participado en las

\footnotetext{
${ }^{25}$ François Machon Tome LIX, deuxième partie 324.

${ }^{26}$ François Machon Tome LIX, deuxième partie 325.

${ }^{27}$ François Machon Tome LIX, deuxième partie 329.

${ }^{28}$ François Machon Tome LIX, première partie 116.
} 
campañas de Roca), ${ }^{29}$ y -sobre todo- de una corrupción que impedía el verdadero desarrollo del territorio. ${ }^{30} \mathrm{Al}$ mismo tiempo, con sus descripciones y consideraciones, Machon nos descubre la situación precaria de los indígenas, en algunas ocasiones convertidos en soldados, ${ }^{31}$ en otras simplemente "vegetando", ${ }^{32}$ y casi siempre viviendo en condiciones miserables.

Las imágenes de desolación, de destrucción y de abandono están siempre presentes. ${ }^{33}$ El suizo se enfrenta a un escenario de crisis, a un contexto en el que los indígenas han perdido casi por completo su capacidad de acción. Y a pesar de todo, el relato de Machon muestra cómo los autóctonos -especialmente los caciquesconservaban aún un cierto poder; un poder que se manifestaba, por ejemplo, en su capacidad para controlar ciertas zonas del territorio de modo que los viajeros que atravesaban dichos lugares debían someterse y respetar las imposiciones y limitaciones impuestas por dichos jefes. Ese poder queda patentado en el relato a través del episodio en el que Machon da cuenta de su encuentro con el hijo del cacique Bartolomé Curruhuinca, hospitalizado en la colonia de Roca. Cuenta Machon que, a pesar de su delicado estado, el indígena tuvo "la fuerza y la amabilidad de dictar una carta de recomendación a nuestro nombre para su inolvidable padre". ${ }^{34}$

Por otra parte, la escritura de Machon deja entrever también una cierta nostalgia por un pasado perdido, un tiempo en el que los indígenas eran los verdaderos dueños del territorio. Sus referencias a los antiguos caciques y, sobre todo, a su gloriosas proezas, constituyen la prueba de la admiración del suizo por ese mundo desaparecido. De esta manera, a lo largo de su texto, desfilan personajes como Catriel y -particularmente- Sayhueque..$^{35}$ Esta rememoración del pasado, marcada por una cierta fascinación, es un buen ejemplo de la desestabilización provocada por el viaje $\mathrm{y}$, sobre todo, de las contradicciones internas del suizo ya que -de manera directa e indirecta- con su periplo y la misión que le había sido encomendada, él contribuía también a la transformación de este espacio y, particularmente, de sus habitantes. A pesar de todo, Machon no puede evitar dejar por escrito su lamento por un mundo desaparecido o en vías de desaparición.

La cuestión de la desaparición (física) de los autóctonos aparece de manera evidente cuando aborda la historia reciente de este territorio. ${ }^{36} \mathrm{Al}$ mismo tiempo, los supervivientes se convierten en objeto de observación y análisis y, a lo largo de su relato, el suizo traza un retrato de los diferentes grupos que habitaban en ese momento el espacio patagónico argentino; sus referencias, bien precisas, muestran su capacidad

\footnotetext{
${ }^{29}$ François Machon Tome LIX, première partie 107.

${ }^{30}$ François Machon Tome LIX, première partie 116.

${ }^{31}$ François Machon Tome LIX, deuxième partie 312.

${ }^{32}$ François Machon Tome LIX, première partie 89.

${ }^{33}$ François Machon Tome LIX, première partie 110.

${ }^{34}$ François Machon Tome LIX, première partie 117.

${ }^{35}$ François Machon Tome LIX, première partie $110 \mathrm{y}$ deuxième partie 321.

${ }^{36}$ François Machon Tome LX cinquième partie 71 y ss.
} 
para reconocer la diversidad étnica y cultural de la región y, de manera indirecta, ponen en evidencia su familiaridad con la literatura especializada de este periodo.

La última parte de su relato constituye una extraordinaria fuente de información en relación a las prácticas y costumbres de las poblaciones autóctonas patagónicas: transmutado en etnógrafo, Machon dibuja un esbozo que pretende ser imagen verdadera de la vida de estos indígenas y aborda cuestiones tan diversas como la vestimenta tradicional, las prácticas de caza, los adornos, la música, el matrimonio e, incluso, las creencias espirituales y las ceremonias funerarias. ${ }^{37}$

Finalmente, Machon en su texto otorga un lugar importante a la descripción de los objetos "característicos" de los indígenas. A lo largo de su relato, la materialidad se convierte en una presencia recurrente. El suizo no puede resistirse a la tentación de recoger diversos artefactos de las poblaciones con las que se va encontrando. Al fin y al cabo, los objetos constituían la prueba evidente de su presencia en el terreno y, sobre todo, de su contacto con el Otro patagónico.

\section{El objeto como prueba: las colecciones patagónicas de Machon}

Según se desprende de su texto, Machon realizó largos trayectos con la única compañía de Santiago Roth, de su baqueano, y de algunos peones. Sin embargo, esta soledad fue más aparente que real ya que, durante todo su periplo, el suizo estuvo siempre acompañado y bien protegido por la presencia (más o menos visible, más o menos cercana) del Ejército y de la Policía argentinos. Fueron precisamente su misión colonizadora y el marco estatal que la amparaba las que le permitieron desarrollar, en paralelo, sus excavaciones "arqueológicas", sus análisis "etnográficos", sus capturas fotográficas y sus acopios de objetos. ${ }^{38}$

Es importante tener en cuenta que el objetivo de su misión no incluía la búsqueda de artefactos ni especímenes destinados a colmar las vitrinas de una institución museística por lo que no había recibido ninguna instrucción en ese sentido ni tampoco consejos específicos sobre el registro de dichas actividades que dieran cuenta, por ejemplo, de los medios empleados para conseguir dichos materiales.

A pesar de todo, su relato ofrece algunas informaciones relevantes relativas a los procesos de adquisición que aparecen íntimamente ligados a la naturaleza de los objetos. Según se desprende del texto, en el caso de los artefactos etnográficos, el medio utilizado para obtenerlos fue, fundamentalmente, la compra. Dos momentos significativos ponen en evidencia el tipo de relación establecida por el suizo con los autóctonos con el fin de conseguir sus objetivos: el primero refiere la adquisición de

\footnotetext{
${ }^{37}$ François Machon Tome LX cinquième partie 70-89.

${ }^{38}$ Sobre otras misiones desarrolladas en el mismo periodo en la región véase Julio Esteban Vezub, "Henry de La Vaulx en Patagonia (1896-1897): la historicidad escindida de la antropología colonial y la captura de corpus y cuerpos", Nuevo Mundo Mundos Nuevos. http://journals.openedition.org/ nuevomundo/57810 (29/11/2009). Consultado el 20 de diciembre de 2019.
} 
unos pocos objetos al viejo cacique Pichalao ${ }^{39}$ el segundo, la compra de uno de los dos quillangos que forman parte de la colección. El primer caso pone de manifiesto la importancia de la diplomacia de la palabra para los indígenas: la conversación constituía un elemento central de las relaciones establecidas no solo en el interior de la comunidad sino también con el exterior; los caciques eran, habitualmente, grandes oradores capaces de parlamentar. La palabra constituía un mecanismo para negociar, pero también para insertar, en cierta manera, al ajeno dentro del grupo. La palabra y la persuasión constituían la base de cualquier acto de negociación; al tiempo, se trataba de una palabra sumamente ritualizada que necesitaba, en la mayor parte de las ocasiones, tiempo. Machon describe las "largas conversaciones" mantenidas con el cacique para lograr su objetivo; unas conversaciones que, según el suizo, pusieron a prueba su paciencia. ${ }^{40}$ El segundo caso pone de manifiesto la importancia de la diplomacia del don utilizada, en este caso, por Machon: al narrar la compra de un quillango en una toldería próxima a la de Pichalao, el suizo relata sus dificultades. La joven indígena, creadora del mismo, se negaba a desprenderse de él por lo que Machon se vio obligado a elevar varias veces el precio de compra. Pese a todo, ella no accedía por lo que el suizo decidió poner en escena otros métodos y así, con el fin de ganarse el favor de los espectadores asistentes a la negociación (y de paso influir indirectamente en la decisión de la joven), comenzó a repartir agujas de coser entre todos los presentes. Finalmente, "después de tres cuartos de hora de negociaciones y de luchas internas, la pequeña propietaria del quillango se decidió y lanzándomelo bruscamente se fue desconsolada a refugiarse en el fondo del toldo". ${ }^{41}$ El regalo (en este caso indirecto) se convirtió así en la vía para aplacar la resistencia de la propietaria.

Dado el periodo en el que realizó su periplo y dados sus propios intereses personales, su práctica coleccionista presenta un carácter mixto: así, el suizo recopila artefactos al tiempo que captura animales salvajes y recoge especímenes zoológicos ${ }^{42}$ y ejemplares geológicos. Desde el punto de vista de la materialidad cultural, Machon se interesa por los objetos etnográficos, testimonios de la realidad contemporánea, sin desdeñar los objetos arqueológicos y los útiles prehistóricos. Se trata por tanto de una recogida de carácter pluridisciplinar en la que aparecen incluso los restos humanos. ${ }^{43}$

\footnotetext{
${ }^{39}$ Puitchualao o Pichalao (Pcha-Lao en el texto de Machon) fue un famoso cacique de la Patagonia. Sus tolderías se ubicaban en la provincia de Río Negro. Moreno lo conoció en 1879 y parece que en ese momento tenía ya, aproximadamente, sesenta años.

${ }^{40}$ François Machon Tome LIX troisième partie 517.

${ }^{41}$ François Machon Tome LIX troisième partie 521.

42 François Machon Tome LX sixième partie 495.

${ }^{43}$ Esas colecciones fueron repartidas entre diferentes instituciones museísticas, fundamentalmente suizas: el grueso de sus colecciones etnográficas y prehistóricas fue donado al Museo de Etnografía de Neuchâtel mientras que una buena parte de sus colecciones de naturalia se conservan en el Museo de Historia natural de esa misma ciudad. Por otro lado, el Museo cantonal de arqueología e historia de Lausana posee algunos objetos y el Museo histórico de esa misma ciudad posee un fondo fotográfico vinculado a él. La Biblioteca Pública y Universitaria de Neuchâtel conserva diecisiete fotografías donadas por él aunque no parecen ser de su autoría. En lo que concierne a los restos humanos, el Museo de Etnografía de Neuchâtel conserva cinco cráneos; el resto fueron donados al Museo de Historia Natural de París. Aún estamos investigando si se produjeron más donaciones de objetos a otras instituciones.
} 
Su interés por las poblaciones patagónicas del pasado le llevó a emprender excavaciones "arqueológicas" en $\operatorname{los}$ paraderos ${ }^{44}$ y cementerios indígenas; una práctica que realizó sin ninguna metodología: sin alzados del terreno y sin apenas descripciones, las informaciones que acompañan estas actividades -y los objetos extraídos- están siempre marcadas por la falta de precisión. A pesar de todo, Machon no renunció a establecer un vínculo entre su trabajo y el realizado por algunos conocidos científicos de la época, como Strobel, Burmeister y, claro está, Moreno. ${ }^{45}$

Entre los materiales recogidos por Machon en los cementerios indígenas sobresalen veintidós cráneos. Esos constituyen el testimonio del interés del suizo por una cuestión central para la Ciencia a finales del siglo XIX: el origen del hombre americano y, en particular, del (denominado) "patagón antiguo". ${ }^{46}$ Muy probablemente, tras ese acopio se hallaba la voluntad de insertar su propia práctica individual dentro de las prácticas institucionalizadas de la comunidad científica y, al tiempo, lograr el reconocimiento de sus "pares". A pesar de su condición de aficionado, Machon logró dar forma a una pequeña colección de antropología física que admiró incluso a René Verneau, uno de los máximos especialistas de este periodo, hasta el punto de que esos cráneos recogidos por el suizo formaron parte de un estudio publicado por el francés en 1894 en el que buscaba establecer una delimitación cronológica y geográfica de los diferentes tipos raciales identificados hasta ese momento en la Patagonia. ${ }^{47}$

En su relato, el suizo da cuenta del largo viaje de estos cráneos desde Argentina hasta Europa y, particularmente, de las peripecias sufridas en el momento de introducirlos dentro del territorio helvético: según él, la administración aduanera "que jamás había visto una mercancía parecida", quería hacerle "pagar los derechos de entrada en relación al peso: tanto por cada cien kilos. Como es obvio, yo protesté señalando que era casi una profanación tasar restos humanos como si fueran huesos de cualquier animal. El honorable empleado me permitió entonces introducirlos libremente bajo este sorprendente epígrafe: Efectos personales usados de inmigrantes. Hoy, todos ellos reposan apaciblemente en las vitrinas de nuestros museos". ${ }^{48}$

Aunque común en la época, la mirada de Machon no deja de resultar sorprendente, sobre todo si la comparamos con la percepción que el suizo tenía frente a otros objetos acopiados. Hay una anécdota particularmente significativa que refleja esta paradoja: Machon describe cómo, una vez en Europa, al desembalar

\footnotetext{
${ }^{44}$ Los paraderos son elevaciones del terreno en las que coinciden espacialmente los productos materiales de actividades domésticas y prácticas mortuorias. En ellos se encuentran mezclados huesos de animales, objetos tallados o labrados y, en ocasiones, restos humanos. Este tipo de enclaves son un rasgo característico del patrón de ocupación prehispánica de la Cuenca del Río Negro. En ellos recogió Machon una buena parte de sus puntas de flecha.

${ }^{45}$ François Machon Tome LX sixième partie 498-499.

${ }^{46}$ Pedro Navarro Floria, Leonardo Salgado y Pedro Azar,"La invención de los ancestros: el «patagón antiguo» y la construcción discursiva de un pasado nacional remoto para la Argentina (1870-1915)", Revista de Indias, vol. LXIV, núm. 231 (2004): 405-424.

${ }^{47}$ René Verneau, «Crânes historiques de Patagonie», L'Anthropologie, 4 (1894): 420-450.

${ }^{48}$ François Machon Tome LX sixième partie 504.
} 
sus colecciones, encontró «en uno de los cráneos un nido de pájaro con un huevo todavía intacto"; El suizo afirma que "nunca habría pensado que estaba sacando un huevo de su nido al apoderarme de esta reliquia. ${ }^{49}$ El verbo utilizado para describir la extracción del cráneo, apoderarse, describe bien muchas de las prácticas asociadas al coleccionismo, marcadas por el ejercicio del poder y la violencia (simbólica). Y, sin embargo, no deja de resultar significativo que la preocupación del suizo se centre en haber sacado un huevo de su nido y no en haber sacado un cráneo de un cementerio. ${ }^{50}$

El acopio de cuerpos indígenas realizado por Machon no se limitó a los muertos, sino que el suizo se esforzó también por apropiarse, simbólicamente, de los vivos. La cámara fotográfica se convirtió así en el instrumento para capturarlos. Estas imágenes debían operar como pruebas que confirmaran su presencia en el terreno y, sobre todo, su contacto con los indígenas. Además, permitían hacer visible la experiencia y, sobre todo, difundirla. El suizo se valió de esta tecnología -signo evidente del progreso- para dejar constancia de su paso por esos lugares considerados culturalmente "arcaicos".

En el proceso de colonización de estos espacios periféricos y su posterior inserción a la nación, la fotografía constituyó un instrumento fundamental; las imágenes físicas y culturales, es decir, las imágenes de los territorios y de sus habitantes originarios, poseyeron una doble función: el conocimiento y la dominación. Aunque su valor es indudable, estas están marcadas por el signo de la contradicción pues portan en sí mismas la paradoja de ser, al mismo tiempo, registro históricoetnográfico e instrumento colonial. ${ }^{51}$ En ese contexto, la fotografía funcionó como un útil privilegiado para la delimitación de los espacios y de las poblaciones consideradas salvajes, exóticas y no civilizadas.

En ciertos pasajes de su relato, Machon señala la frontal oposición de algunos autóctonos a ser retratados. ${ }^{52}$ A pesar de todo, logró tomar diferentes fotografías que acabaron formando parte de las colecciones museísticas.

En 1901, el suizo abandonó definitivamente la Argentina. Instalado en un primer momento en París y, posteriormente, en Lausana, Machon puso en marcha una serie de acciones destinadas a construirse una identidad socio-profesional sólida que le permitiera ubicarse en una determinada taxonomía de credibilidad científica, estatus y legitimidad, y, al tiempo, ser reconocido por sus pares y recordado por sus compatriotas. Así, por ejemplo, fue miembro activo de algunas reconocidas Sociedades científicas de la Suiza francófona de la época, ${ }^{53}$ desplegó una intensa

\footnotetext{
${ }^{49}$ François Machon Tome LIX troisième partie 516.

${ }^{50}$ En el caso del texto original resulta aún más significativo porque el verbo "dénicher" posee en francés un doble sentido: retirar los huevos de un nido de pájaros, y hacer salir a alguien de algún sitio por la fuerza.

${ }^{51}$ Lía Colombino, "Viaje, tiempo, imagen y violencia: Trazas de lectura en las fotografías de Louis de Boccard", Louis de Boccard: Un fotógrafo en la Triple Frontera, 1889-1956, editores André Heráclio do Rêgo y Rubén Capdevila, (Asunción: Embajada de Brasil, 2017) 113.

${ }^{52}$ François Machon Tome LIX deuxième partie 335-336.

${ }_{53}$ Machon fue miembro de numerosas sociedades, entre ellas, la Sociedad de Ciencias Naturales de Vaud (desde 1893), donde llegó a ser presidente (1910), la Sociedad de Ciencias Naturales de Neuchâtel, la
} 
actividad de mediación-divulgación ${ }^{54}$ y estableció una fructífera y duradera relación con el Museo de Etnografía de Neuchâtel. Esta última acción habría de otorgarle no solo el reconocimiento social, sino, sobre todo, la perdurabilidad de este.

\section{Eldesiertoen lavitrina: musealización yarqueologización de los indígenas patagónicos}

La entrada en el Museo de Etnografía de Neuchâtel de las colecciones patagónicas recogidas por Machon se fraguó en 1926. Ese año, el suizo, quien desde 1903 ostentaba el cargo de cónsul del Paraguay en Lausana, contactó con la institución interesado por un objeto muy particular: una dalmática que había sido donada al Museo en 1889 por el entonces cónsul de Argentina en la ciudad de Neuchâtel, Monsieur Wuille-Bille. Esta pieza, a la que los documentos institucionales denominan casulla, parece que tenía su origen en el pillaje llevado a cabo en la catedral de Asunción durante la Guerra de la Triple Alianza (1864-1870).

Machon propuso al entonces director del Museo, Théodore Delachaux, restituir la dalmática al Paraguay y, como contrapartida, se ofreció a donar a la institución su propia colección de objetos etnográficos y arqueológicos, aunque solicitó que dicha transacción permaneciese en secreto. ${ }^{55}$ Tras diferentes vicisitudes, el acuerdo llegó a buen término y la dalmática fue devuelta a la nación paraguaya. Al tiempo, una parte de las colecciones del suizo ingresaron en el Museo. La donación, en la que destacan los objetos etnográficos, quedó consignada en una lista; a pesar de su aparente simplicidad, este documento constituye un (micro)compendio de significaciones; es la concreción discursiva y visual de un conocimiento generado en unas coordenadas espacio-temporales determinadas $\mathrm{y}$, en consecuencia, el reflejo de una manera de construir sentido(s). Se trata de una materialidad especialmente reveladora que contiene preciadas informaciones como las referencias a las tolderías en que fueron recogidos los objetos y, especialmente, a sus caciques. ${ }^{56}$ Por esa razón, a pesar de su reducido número, estos artefactos etnográficos poseen un valor simbólico particularmente importante.

\footnotetext{
Sociedad de Medicina de Vaud y la Sociedad Suiza de Neurología.

${ }^{54}$ Machon buscó aproximar su experiencia etnográfica a una comunidad más amplia y se convirtió en un activo colaborador de la Gazette de Lausanne, periódico en el que publicó numerosos artículos vinculados al mundo americano. Al tiempo, desplegó una intensa actividad como conferenciante; el "profundo conocimiento" adquirido a lo largo de sus estancias en el extremo sur del continente le permitió incursionar no solo en la etnografía, sino, también, en temáticas históricas, socioeconómicas e, incluso, políticas.

${ }^{55}$ Sobre las cuestiones jurídicas relativas a esta restitución véase: Raphael Contel, Anne Laure Bandle, Bernard Knodel y Marc-André Renold, "Affaire Chasuble. Paraguay et Musée d'ethnographie de Neuchâtel et François Machon”, marzo de 2012. https://plone.unige.ch/art-adr/cases-affaires/chasuble2013-paraguay-et-musee-d2019ethnographie-de-neuchatel-et-francois-machon/fiche-affairechasuble

${ }^{56}$ Aparecen nombres como Pichalao y Galache. Muy probablemente se trata del cacique Galache Kánkel (Kengel), un cacique Tehuelche que habitó la región del Chubut y que se hizo famoso por haber capturado dos veces al famosos bandido Asencio Brunel, y entregárselo después a las autoridades. Parece que era hermano del también cacique Cahuel.
} 
A esa donación de objetos se sumó la entrega de una serie de fotografías realizadas por el propio Machon durante su periplo en la Patagonia. ${ }^{57} \mathrm{Su}$ valor etnográfico e histórico es innegable: son un testimonio del proceso de dominación de los territorios patagónicos y de sus habitantes, y constituyen una metáfora del triunfo de una ideología que se hacía presente en esos remotos rincones. Insertadas en las colecciones del Museo, estas imágenes tuvieron efectos reales y concretos ya que contribuyeron a determinar la organización del conocimiento sobre estas poblaciones $\mathrm{y}$, al tiempo, desempeñaron un relevante papel en la construcción de un imaginario sobre los indígenas patagónicos. Fueron una suerte de archivo visual destinado a reforzar el carácter y el sentido de las colecciones. (Figura 2) ) $^{58}$

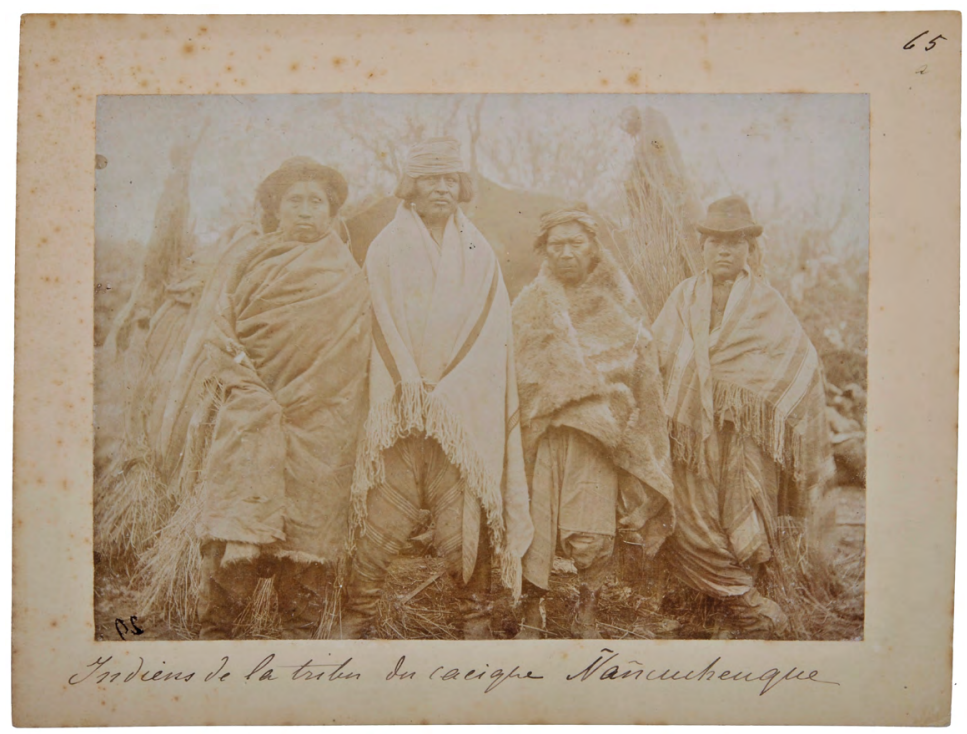

Figura 2. François Machon. "Indígenas de la tribu del cacique Ñancucheuque" Patagonia (Argentina), 1892 @ Museo de Etnografía de Neuchâtel, Neuchâtel (Suiza) MEN P.1926.1.11

El trabajo fotográfico de Machon resulta interesante por la ambivalencia entre la individualización y la anonimización de los retratados, así como por la dicotomía entre presencia y ausencia indígena. Por otro lado, este corpus de imágenes

\footnotetext{
${ }^{57}$ El fondo, catalogado con los números de inventario P.1926.1-38, está compuesto por 38 fotografías. Todas ellas están acompañadas de una leyenda y presentan una numeración en la parte superior derecha. Por el momento, no conocemos el significado de estas cifras. Puede tratarse de una clasificación secuencial establecida por el propio donante; si fuera el caso, el fondo original habría sido mucho más numeroso que el conservado actualmente en el Museo. También es posible que el número esté asociado a una particular disposición dentro del texto: el relato original no presenta imágenes, pero es posible que Machon estableciese un vínculo (hasta ahora no descifrado) entre el texto y las fotografías.

${ }^{58}$ Según se desprende del propio relato de Machon, esta fotografía debió ser tomada el 9 de mayo. Según el suizo, se trataba de un grupo 16 indígenas entre los que había 2 mujeres y algunos niños. Machon señala que debían haber tenido contacto previo y habitual con los blancos pues se dejaban fotografiar fácilmente. François Machon Tome LIX troisième partie 499.
} 
constituye un rastro del proceso colonizador y de sus efectos. Y aunque la violencia parece ausente, está sutilmente presente. Finalmente, algunas de estas imágenes son particularmente significativas porque hacen visibles (directa o indirectamente) las prácticas de recogida de objetos llevadas a cabo por Machon, especialmente las excavaciones en los paraderos o cementerios indígenas. En esas fotografías se hacen presentes no ya los vivos sino los restos de sus antepasados, convertidos en testimonio. (Figura 3) $)^{59}$

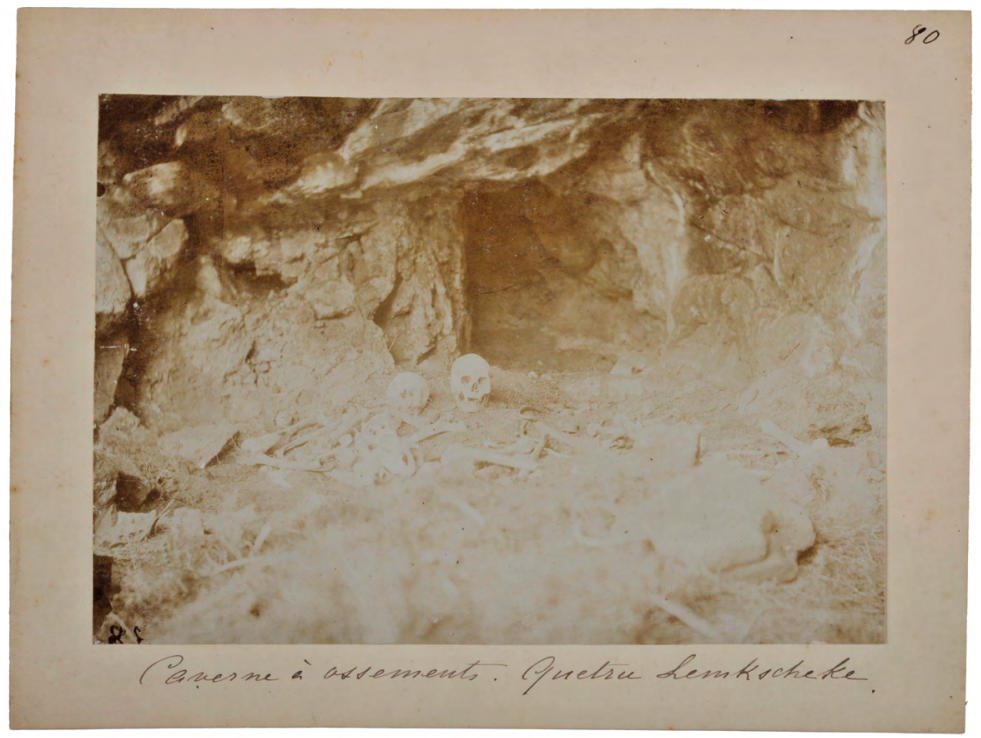

Figura 3. François Machon, "Caverna de huesos. Quetru Lemkscheke” Patagonia (Argentina), 1892 (C) Museo de Etnografía de Neuchâtel, Neuchâtel (Suiza) MEN P.1926.1.20

En 1927, un año después de este acuerdo diplomático, el suizo hizo una nueva donación a la institución. Entre los objetos cedidos se hallaba una buena parte de sus colecciones etnográficas, así como todos los útiles prehistóricos recogidos durante su viaje por la Patagonia. Para Machon, esas piezas constituían lo más interesante de su colección, lo que verdaderamente merecía la pena y debía retener la atención de los visitantes.

La llegada de las colecciones de Machon al Museo de Etnografía de Neuchâtel se produjo en un momento particular: en el contexto científico de los inicios del siglo $\mathrm{XX}$, dos de las preocupaciones más acuciantes de las instituciones museísticas eran, por un lado, llenar los vacíos de la cartografía etnográfica y, por otro, registrar y dejar constancia visual de aquellos pueblos considerados primitivos y al borde de la desaparición. En el caso particular de Neuchâtel, estas preocupaciones toman forma en la figura de Théodore Delachaux, en esas fechas director de la institución (1921-

\footnotetext{
${ }^{59}$ Según se desprende del propio relato de Machon, esta fotografía debió ser tomada el 17 de mayo de 1892.
} 
1945). Delachaux consideraba que era imprescindible "salvar los últimos vestigios de la industria de la humanidad primitiva mientras aún se pueda"; en su opinión, el Museo poseía una obligación moral para con la sociedad y con sus descendientes: "acumular en nuestras colecciones un material precioso, testigo para ellos de los tiempos pasados". ${ }^{60}$

Los objetos donados por Machon se ajustaban perfectamente a estas premisas: en primer lugar, una parte de esos objetos pertenecían a poblaciones consideradas en riesgo de desaparición; en segundo lugar, otra parte de ellos -como los útiles prehistóricos- constituían las pruebas de un pasado desaparecido que podía contribuir a dar luz al presente. Sin duda, material privilegiado para la ciencia.

La importancia otorgada a estos objetos fue tal que su entrada condujo a una reorganización total del espacio expositivo. Así, en 1928, las colecciones de la región andina fueron desplazadas a la galería del hall y los objetos de la región amazónica fueron sacados de la exposición permanente en espera de encontrar un espacio en el que ubicarlos. ${ }^{61}$ A partir de este momento, las colecciones Machon se convirtieron en el eje fundamental del discurso sobre América.

A pesar de que estas colecciones representaban una realidad espacial y cultural particularmente fragmentaria, el discurso visual desplegado a través de las vitrinas se pretendía continental. De esta manera, unos pocos objetos escogidos creaban la ilusión de constituir una verdadera representación del mundo americano.

Uno de los elementos más singulares de este proceso es la peculiar relación establecida entre Theodore Delachaux, y François Machon; en esta puesta en escena de la realidad americana, el director del Museo, verdadero renovador de la institución, sucumbió a la voluntad del donante. El regalo ofrecido por Machon contenía un calculado sentido de trascendencia ya que el don entrañaba una importante contraprestación: la exigencia de la exposición de los objetos. La correspondencia establecida con Delachaux pone en evidencia que para el doctor era absolutamente indispensable que estos fueran expuestos y no conservados en un almacén. Pero, además, la donación conllevaba ciertas directrices acerca de la puesta en escena de los mismos: Delachaux decidió reservar a Machon la serie de vitrinas de la sala americana ubicadas en los lados norte y oeste. ${ }^{62}$ Ambos acuerdan retirar otra vitrina (la ubicada entre las dos ventanas) con el fin de liberar toda una pared y así poder instalar, en el medio de este espacio, una serie de vitrinas horizontales destinadas a contener los útiles prehistóricos procedentes de la Patagonia. ${ }^{63}$ (Figura 4)

\footnotetext{
${ }^{60}$ Théodore Delachaux, "Musée ethnographique de Neuchâtel. Rapports sur l'exercices 1927, 1928 et 1929”, Bulletin de la Société neuchâteloise de géographie, 39 (1930): 136.

${ }^{61}$ Théodore Delachaux 134.

${ }^{62}$ En realidad, como puede observarse a partir del croquis y de las fotografías, se trata de los lados norte y este.

${ }^{63}$ François Machon, "Carta de F. Machon a T. Delachaux”, Pully (Suiza), 21 de octubre de 1927. Archivos del Museo de Etnografía de Neuchâtel, Neuchâtel (Suiza), Fondo Machon.
} 


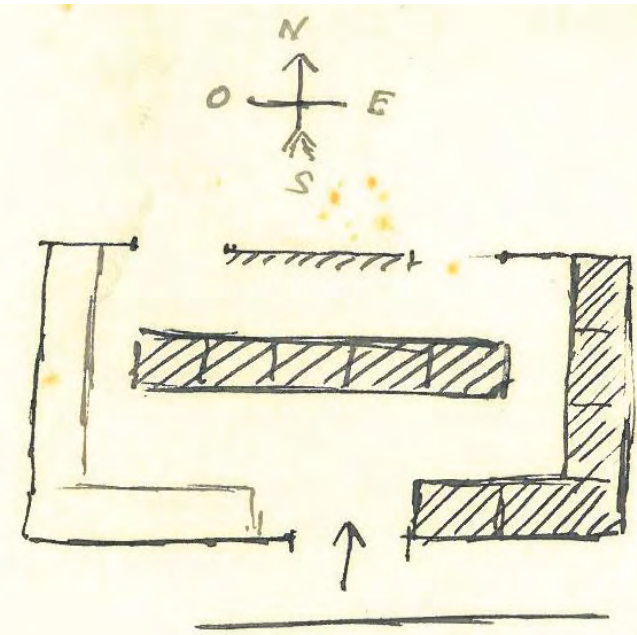

Figura 4. François Machon, "Croquis que muestra la disposición de las vitrinas en la sala América", 1926 (C) Museo de Etnografía de Neuchâtel, Neuchâtel (Suiza)

La experiencia de Machon sobre el terreno le otorgaba legitimidad; él era el "verdadero" conocedor de la realidad indígena y, por tanto, estaba en condiciones de "imponer" las pautas que habían de regir la exposición de sus colecciones. Su (aparentemente) humilde solicitud de participar en la puesta en escena de los objetos y su (premeditado) ofrecimiento de realizar las etiquetas que debían acompañarlos con el fin de que ninguna información importante fuera omitida constituyen la constatación del importante rol jugado por el donante $y$, sobre todo, de su voluntad de utilizar estas colecciones como un mecanismo para afianzar su prestigio (social y científico), y lograr el (definitivo) reconocimiento de sus pares y de su propia comunidad de pertenencia, la ciudad de Neuchâtel.

Con la aceptación de sus propuestas, la institución estaba contribuyendo a consolidar y legitimar la autoridad del doctor y, al tiempo, a hacerla visible a través de sus vitrinas. Pero, sobre todo, con la asunción de las directrices del donante, el Museo contribuyó a institucionalizar, perpetuar y propagar una mirada -subjetiva y fragmentaria- sobre las poblaciones indígenas americanas, particularmente, sobre las patagónicas.

Gran parte de la sala pivotaba en torno a las colecciones procedentes de esa región geográfica, y se sustentaba -de manera particular- en los útiles prehistóricos: los muebles-vitrina emplazados en el centro de la misma presentaban puntas de flecha, raspadores y buriles, mientras que una de las vitrinas -ubicada en un lugar estratégico y flanqueada por los quillangos- mostraba los cráneos de los antiguos habitantes de este territorio (Figura 5). La mayor parte de los objetos presentados 
correspondían a indígenas desaparecidos o, como señalaba el propio Machon, en vías de desaparición. Esta puesta en escena contribuyó, sin duda, a trasmitir una imagen de la Patagonia marcada por la arqueologización. Finalmente, la configuración global de la sala -sustentada de manera central en las colecciones americanas de Machon, procedentes de espacios "marginales" y considerados como no contaminadospropició la construcción de una imagen cultural del Nuevo Mundo que giraba en torno al pasado, el exotismo y el primitivismo.

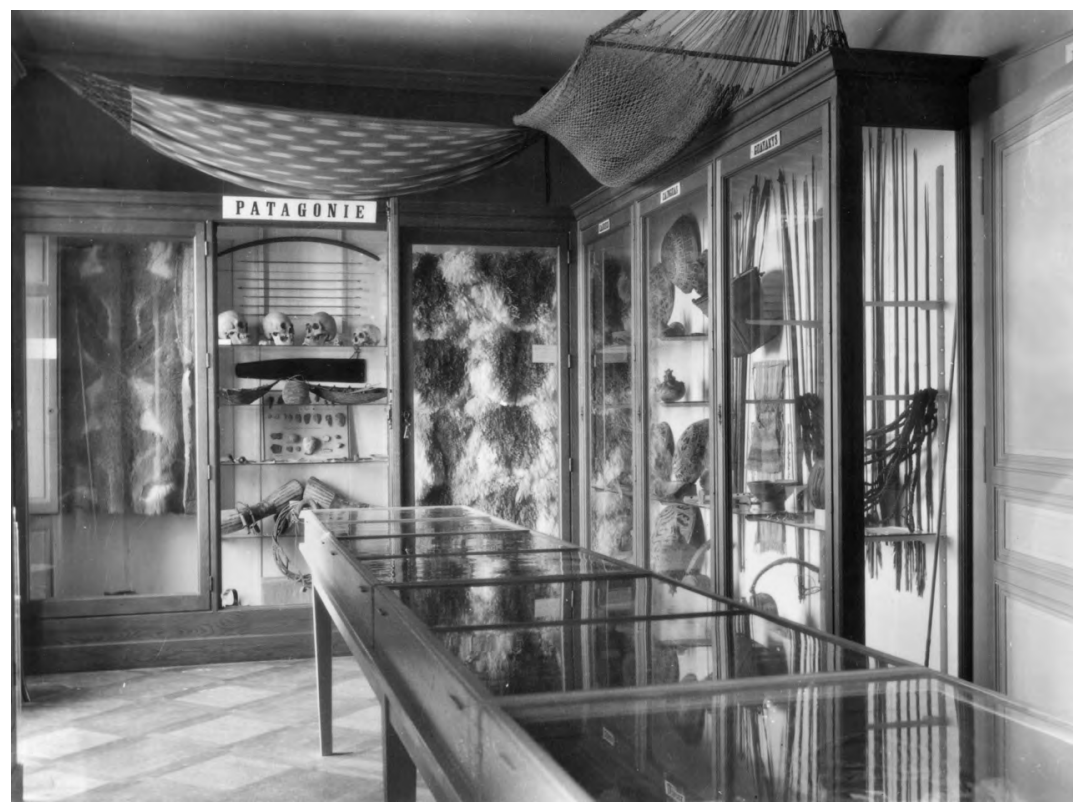

Figura 5. Autor desconocido. "Sala América", Años 30 @ Museo de Etnografía de Neuchâtel, Neuchâtel (Suiza)

\section{Conclusiones}

Como hemos visto a lo largo de las páginas precedentes, el viaje de Machon se enmarca en un contexto muy particular, la Argentina de finales del siglo XIX, una nación en construcción tanto desde el punto de vista simbólico como territorial. El objetivo de la misión que se le había encomendado aparece claramente explicitado al inicio del relato y muestra hasta qué punto el suizo fue partícipe de un proyecto destinado a transformar un territorio. Su periplo está directamente vinculado a la voluntad del Estado argentino de convertir la Patagonia en un desierto fecundable y poblado por colonos blancos.

Sin embargo, a lo largo de todo su relato, Machon no se presenta nunca como un agente de este proceso de colonización. Más bien al contrario, se muestra ante nuestros ojos como un observador imparcial; sus descripciones y comentarios aparecen como el resultado de un interés exclusivamente científico. Su texto está marcado por la autonegación de su condición, un rasgo característico de lo que 
Mary Pratt ha denominado literatura de anticonquista. Solo al final de su relato recupera Machon su rol de agente de este proceso y lo hace para desaconsejar la agricultura en estas regiones. Al tiempo, es en ese momento cuando nos desvela la verdadera intención de su trabajo de escritura: servir a la comunidad advirtiendo a sus compatriotas "contra las tentadoras promesas y las descripciones fantásticas" para evitar una emigración estéril.

La autonegación de Machon se complementa con una autoafirmación no explicitada: la de presentarse como un científico (amateur) que se esfuerza por contribuir al conocimiento sobre esta región y al desarrollo de la ciencia. Esta (otra) vocación de utilidad se tradujo en un relato plagado de informaciones geológicas, botánicas, zoológicas, arqueológicas, históricas y, por supuesto, etnográficas.

Pero el suizo no se limitó a construir un discurso sobre la Patagonia, sino que buscó también materializarlo; por esa razón, a lo largo de su periplo, se esforzó por acopiar objetos que dieran cuenta del pasado y el presente de las poblaciones que habitaban ese territorio. Al tiempo, capturó -física o simbólicamente- sus cuerpos. Las imágenes, los artefactos, los restos humanos y las naturalia constituían materiales (científicos) privilegiados que testimoniaban su presencia sobre el terreno.

$\mathrm{Su}$ "voluntad de servicio" a la comunidad culminó, años después, con la donación de la mayor parte de sus colecciones al Museo de Etnografía de la ciudad de Neuchâtel, su pequeña patria de origen. El museo constituía el espacio ideal para lograr el reconocimiento social de su práctica y, sobre todo, su institucionalización. La musealización constituía, en realidad, el culmen de un proceso de autoafirmación personal y de construcción de una identidad científica.

Pese a que el nombre de Machon no es recordado entre los avezados exploradores, ni figura en las listas de los avanzados etnólogos ni de los renombrados naturalistas, su trayectoria reviste una singular importancia para el Museo de Etnografía de Neuchâtel ya que permite repensar y reescribir (críticamente) el pasado de esta institución. Pero la relevancia del personaje supera con creces los límites de la historia de un museo local ya que su viaje, su relato y los objetos que recogió en la Patagonia constituyen un instrumento privilegiado para abordar el análisis de eso que denominamos la "triple c", es decir, las intersecciones entre colonización, ciencia y coleccionismo, así como para reexaminar las colecciones contenidas en museos ubicados en lugares (aparentemente) ajenos a los procesos de expansión colonial decimonónicos y, en consecuencia, para repensar el colonialismo mismo desde los márgenes.

\section{Cuestiones pendientes}

Habitualmente, los trabajos académicos como el que aquí presentamos suelen finalizar y clausurarse con las conclusiones. Sin embargo, este escrito no es un texto cerrado, y no lo es por dos razones: por todo lo que queda por saber y por todo lo que queda por hacer. En lo que respecta a los vacios y lagunas de esta investigación, 
falta conocer cómo se gestó realmente este viaje, así como los términos del acuerdo suscrito por Machon para llevar a cabo su misión. Queda también pendiente la tarea de analizar y valorar el verdadero rol de Machon dentro de los procesos de construcción del conocimiento científico a finales del siglo XIX, así como sus aproximaciones y distanciamientos en relación a la disciplina etnográfica. Falta aún realizar la ingente tarea que supone volver a vincular unas colecciones afectadas por la división establecida entre historia natural, historia cultural, antropología física y etnografía, una clasificación (artificial) que ha provocado la dispersión de los fondos entre varias instituciones; es necesario abordarlos, pensarlos y problematizarlos de manera integral. Queda por abordar el estudio sociocultural de los restos humanos recolectados por Machon así como identificar -en la medida de lo posible- su procedencia geográfica precisa. Falta realizar un trabajo de análisis profundo de las fotografías que permita una (cierta) individualización de los representados, la ubicación geográfica precisa de las tolderías y de los lugares en que dichas imágenes fueron tomadas, así como la reconexión entre esos hombres y mujeres con los objetos recogidos.

Solo entonces será posible (re)ubicar estas colecciones en su contexto histórico. Solo de esta forma será posible otorgarlas el verdadero rol memorial que poseen y, por ende, reactivarlas. Solo así será posible imaginar un futuro marcado por nuevas prácticas museísticas; prácticas que desactiven el rol del museo como simple depósito de objetos y lo transformen en un espacio capaz de reconectar colecciones fragmentadas y de reconstituir historias escindidas.

\section{Bibliografía}

\section{Fuentes primarias}

\section{Fuentes de archivo}

Archivo del Museo de Etnografía de Neuchâtel, Suiza. Fondo François Machon

\section{Prensa}

L'Impartial, 16 mars 1886.

Feuille d'avis de Neuchâtel, 19 juin 1886, 29 mars 1887 y 5 avril 1887.

\section{Visual}

Fondo fotográfico del Museo de Etnografía de Neuchâtel, Suiza 
De relatos de anticonquista, coleccionismo y musealizaciones: François Machon en la...

\section{Fuentes secundarias}

\section{Libros}

Alberdi, Juan Bautista. Bases y puntos de partida para la organización política de la República Argentina. Buenos Aires: Biblioteca del Congreso de la Nación, 2017.

Livon-Grosman, Ernesto. Geografías imaginarias. El relato de viaje y la construcción del espacio patagónico. Rosario: Beatriz Viterbo Editora, 2003.

Machon, Jorge F. y Juárez, Francisco N. Juárez (eds.). Patagonia 1892. Diario del explorador Suizo Dr. Francisco Machón. Buenos Aires: Editorial Dunken, 2013.

Mases, Enrique H. Estado y cuestión indígena. El destino final de los indios sometidos en el fin del territorio (1878-1910). Buenos Aires: Prometeo libros/Entrepasados, 2002.

Westphal, Bertand. La Géocritique. Réel, fiction, espace. Paris: Minuit, 2007.

\section{Capítulos de libros}

Colombino, Lía. "Viaje, tiempo, imagen y violencia: Trazas de lectura en las fotografías de Louis de Boccard", Louis de Boccard: Un fotógrafo en la Triple Frontera, 1889-1956, editores André Heráclio do Rêgo y Rubén Capdevila. Asunción: Embajada de Brasil, 2017.

Lazzari, Alex y Nigg, Regula. "El médico alemán, o cómo reconocer una etnografíaaccidente en la antropología Argentina”. El americanismo germano en la antropología Argentina, compilado por Lena Dávila y Patricia Arenas. Buenos Aires: Ediciones CICCUS. En prensa.

Podgorny, Irina y otros. "Caballeros de la noche. Antropología y museos en la Argentina de las últimas décadas del siglo XIX". Las ciencias en la formación de las naciones americanas, coordinado por Sandra Katja Carrillo Zeiter. Madrid: Iberoamericana, 2014.

\section{Artículos de revistas}

Delachaux, Théodore. "Musée ethnographique de Neuchâtel. Rapports sur l'exercices 1927, 1928 et 1929”. Bulletin de la Société neuchâteloise de géographie 39 (1930): $132-137$.

Machon, François. «En Patagonie. Notes d'un explorateur». Bibliothèque Universelle et Revue Suisse, Tome LIX y Tome LX. (1893): 79-118, 307-338, 495-521 y 7096, 284-308 y 492-521. 
Morgan Meyer. "On the Boundaries and Partial Connections between Amateurs and Professionals". Museum and Society, vol. 6.1. (2008): 38-53.

Navarro Floria, Pedro. "El desierto y la cuestión del territorio en el discurso político argentino sobre la frontera Sur". Revista de Historia complutense de historia de América 28. (2002): 139-168.

Navarro Floria, Pedro, Salgado, Leonardo y Azar, Pedro. "La invención de los ancestros: el «patagón antiguo» y la construcción discursiva de un pasado nacional remoto para la Argentina (1870-1915)". Revista de Indias LXIV. 231 (2004): 405 424.

Star, Susan Leigh y Griesemer, James. "Institutional Ecology, Translations, and Boundary Objects: Amateurs and Professionals in Berkeley's Museum of Vertebrate Zoology”. Social Studies of Science, vol. 19. (1989): 387-420.

Verneau, René. «Crânes historiques de Patagonie». L’Anthropologie 4. (1894): 420450 .

\section{Tesis, ponencias y otros}

Follonier, Selina. «Devenir soi-même». Paris, catalyseur de l'identité romande. Reconversions d'écrivains transfuges (1880-1900). Mémoire de maîtrise, Université de Lausanne, 2017.

Lenton, Diana. "De centauros a protegidos. La construcción del sujeto de la política indigenista Argentina desde los debates parlamentarios (1880-1970). Tesis doctoral, Universidad de Buenos Aires, 2005.

\section{Publicaciones en Internet}

https://plone.unige.ch/art-adr/cases-affaires/chasuble-2013-paraguay-et-museed2019ethnographie-de-neuchatel-et-francois-machon/fiche-affairechasuble

http://doi.org/10.3917/aj.441.0070

http://journals.openedition.org/corpusarchivos/1159

http://journals.openedition.org/nuevomundo/57810

http://ppct.caicyt.gov.ar/index.php/corpus/issue/view/30/showToc 